\title{
Numerical Simulation of Varied Buffer Layer of Solar Cells Based on Cigs
}

\author{
Sampson Oladapo Oyedele, Boko Aka* \\ Université Nangui Abrogoua, UFR des Sciences Fondamentales et Appliquées (SFA) et Institut de Recherche sur les Energies \\ Nouvelles (IREN), Abidjan, Côte d'Ivoire \\ Email: *bokom2010@gmail.com
}

How to cite this paper: Oyedele, S.O. and Aka, B. (2017) Numerical Simulation of Varied Buffer Layer of Solar Cells Based on Cigs. Modeling and Numerical Simulation of Material Science, 7, 33-45.

https://doi.org/10.4236/mnsms.2017.73003

Received: June 17, 2017

Accepted: July 27, 2017

Published: July 30, 2017

Copyright (c) 2017 by authors and Scientific Research Publishing Inc. This work is licensed under the Creative Commons Attribution International License (CC BY 4.0).

http://creativecommons.org/licenses/by/4.0/

cc) (i) Open Access

\begin{abstract}
Numerical simulation has been used to investigate the effect of different buffer layer components on the performance of $\mathrm{CuInGaSe}_{2}$ solar cells with SCAPS-1D software. The main photovoltaic parameters of simulated devices: open-circuit voltage (Voc), short-circuit current (Jsc), fill factor ( $\mathrm{FF}$ ), and conversion efficiency $(\eta)$, are analysed as a function of thickness and temperature in the different buffer layers used. According to numerical simulation the highest conversion efficiency (23\%) of CIGS solar cell is reached for the CdS buffer layer. This result is validated by experimental results $(20 \%)$. At $300 \mathrm{~K}$, when the thickness of the buffer layer (CdS, ZnS, ZnSe, $\mathrm{InSe}_{2}$ ) increases from $100 \mathrm{~nm}$ to $500 \mathrm{~nm}$, with the other parameters maintained constant, the efficiency decreases. When the temperature increases from $300 \mathrm{~K}$ to $400 \mathrm{~K}$, with the other parameters maintained constant, both open circuit voltage and conversion efficiency also decrease. The effect of dual buffer layers of $\mathrm{ZnS} / \mathrm{CdS}$ has also been analysed and his efficiency increases of $3 \%$ than a single buffer CdS.
\end{abstract}

\section{Keywords}

Numerical Simulation, CIGS Solar Cell, SCAPS-1D, Buffer Layer, Efficiency

\section{Introduction}

The growth of the world's population and industrial development of industrialized countries is leading to an increase in energy need. Worldwide, current energy production is mainly based on fossil fuels but it pollutes the environment and raises the relative proportion of greenhouse gases in the atmosphere. The detrimental effects of non-renewable resources on our environment have led to a greater awareness generating the conference of PARIS [1]. This conference of PARIS encouraged the use of renewable energies like photovoltaic energy. Solar energy can 
be harvested with photovoltaic (PV) cells solar-cells.

The CIGS solar cell is one of the promising solar cells. The efficiency of CIGS is up to $23 \%$ [2] one of the best efficiency of a thin film. The CIGS solar cell has also many merits. It has a variable band gap (from $1.06 \mathrm{eV}$ to $1.7 \mathrm{eV}$ ) and has also a high optical absorption coefficient and a direct band gap. The solar cell is commonly used with a configuration of "glass/Mo/CIGS/buffer/i-ZnO/transparent conductive oxide (TCO)". On CIGS solar cell structure, the buffer layer intermediates between the absorber layer and window layer. It improves generally the cell efficiency and has many tasks:

- Forms a junction with the absorber layer while admitting a maximum amount of light to the junction region and absorber layer [3];

- Provides a low resistive path to contacts;

- Fixes the electrostatic conditions inside the absorber layer [4];

- Protects the junction electrically and mechanically against the damage that may other side be caused by oxide.

From the electronic point of view, since buffer layers are usually highly-resistive, they serve as intermediate layers that can prevent shunting between the TCO and the absorber [5].

From the technological point of view, buffer-layers can protect the absorber surface from damage by high-energy ions during the $\mathrm{n}^{+} \mathrm{ZnO}$ deposition by RF-sputtering. From the chemistry point of view, chemical constituents of buffer material passivize CIGS surface defects and/or dope the CIGS near-surface layer.

And finally, from the physics point of view, buffer layers affect the band structure. Buffer layers affect the band offsets and also the electric field in the junction, and thus the current transport [6]. It has proved that omitted the buffer layer result in lower efficiency [7].

So, we need to choose carefully the buffer layer to improve the device performance. The material must obey to this criterion. The requirements are listed below:

- This layer should have minimal absorption losses;

- Large energy band gap for high optical transmission in the visible region;

- An optimum band structure;

- The juxtaposition of crystal structures at the junction must be great so as to generate the fewest defects (and thus recombination centers) possible during the growth of the buffer layer; for the same reasons, the compound should be stable over time;

- The n-doping of the buffer layer should ideally be higher than that of the absorber so as to confine the Space Charge Region (SCR) in the absorber; high doping density is also necessary to prevent the generation of minority carriers, thereby reducing the reverse current, however, too high a doping could also cause a recombination tunnel current to the interface in the case of a high band discontinuity;

- The process and material choice of the buffer layer should provide an alignment of the conduction band with the $\mathrm{Cu}$ (In, Ga) $\mathrm{Se}_{2}$ absorber with an energy 
conduction of $0-0.4 \mathrm{eV}$.

The buffer usually used for CIGS solar cell is CdS but due to the toxicity of cadmium sulfide (CdS) many countries have prohibited the cadmium sulfide (CdS) and also due to a low band gap of CdS $(2.4 \mathrm{eV})$, only a lower fraction of photons are available for CIGS absorber this leads to loss of current in the blue region of the solar spectrum and hence limits the solar cell performance; serious efforts have been made to substitute the CdS buffer by other non-toxicity layer like CIGS based thin film can be a mark. To change the CdS:

- The material should be n-type in order to form a p-n junction with the absorber layer;

- The bandgap should be wide for limited light absorption;

- A wide band gap, greater than that of $\mathrm{CdS}$, in order to transmit a maximum of photons to the absorber.

So in this work, we use different buffer layers and by simulation with SCAPS1-D [8], we discuss their effects in the CIGS base cell performances. We also studied the impact of buffer thickness and effect of variable temperature on PV performance. In order to improve the efficiency of CIGS based cell, we use the dual buffer and we studied their effect on photovoltaic (PV) parameters.

\section{Methodology}

\subsection{Cell Structure}

The photovoltaic structure to be studied is based on CIGS absorber with alternative buffer layer as $\mathrm{ZnO}$ as window layer and front contact Molybdenum (Mo) taken as front contact. This used configuration for a CIGS solar cell as shown in Figure 1.

\subsection{Input Parameters}

In order to run numerical simulation calculations, the baseline parameters of all the components of the solar cell have to be defined to be used as inputs for SCAPS software. Theses parameters can be grouped in two sets: parameters for CIGS solar cell and parameters for variable buffer layers. The thickness of CIGS is two (2) $\mu \mathrm{m}$ and we varied the thickness of the varied buffer (CdS, $\mathrm{ZnS}, \mathrm{ZnSe}$,

\begin{tabular}{|c|}
\hline Front contact n-doped $\mathrm{ZnO}$ \\
\hline Window layer i-ZnO \\
\hline Buffer layer (CdS, $\left.\mathrm{ZnS}_{2}, \mathrm{In}_{2} \mathrm{~S}_{2}, \mathrm{ZnSe} . ..\right)$ \\
\hline Absorber layer $\mathrm{Cu}\left(\ln \mathrm{x} \mathrm{Ga}{ }_{1-\mathrm{x}}\right) \mathrm{Se}_{2}$ \\
\hline Back contact (Molybdenum) \\
\hline Substrate (Soda lime glass, Ti,Polyimide...) \\
\hline
\end{tabular}

Figure 1. Schematic diagram of the CIGS based solar cell. 
$\mathrm{In}_{2} \mathrm{~S}_{2}$ ) from $0.1 \mu \mathrm{m}$ to $0.5 \mu \mathrm{m}$ and the temperature of solar cell from $300 \mathrm{~K}$ to 400 $\mathrm{K}$. All these materials are well known materials and their properties can be easily found in the literature and experimental studies available in the references [9]. The structure has been studied under solar spectrum AM 1.5 with $\mathrm{P}=1000 \mathrm{~W} / \mathrm{m}^{2}$ and at a temperature $\mathrm{T}=300 \mathrm{~K}$. The simulation of the photovoltaic parameters has been made without considering the influences of the series and shunt resistance (Table 1).

\section{Results and Discussion}

\subsection{Simulation of Solar Cell by Changing the Buffer Layer Materials}

We simulated a varied buffer layer with a thickness of $0.1 \mu \mathrm{m}$ and we compared the main photovoltaic (PV) parameters for both simulated and experimental data (Table 2).

Table 1. Physical parameters used in simulation.

\begin{tabular}{cccccc}
\hline & CIGS & CdS & ZnS & ZnSe & In $_{2} \mathbf{S}_{2}$ \\
\hline Thickness $(\mu \mathrm{m})$ & 2 & varied & Varied & Varied & varied \\
Band gap $(\mathrm{eV})$ & 1.2 & 2.400 & 3.500 & 2.900 & 2.800 \\
Electron affinity $(\mathrm{eV})$ & 4.5 & 4.500 & 4.500 & 4.090 & 4.700 \\
Dielectric permittivity $(\mathrm{relative})$ & 13.6 & 10.000 & 10.000 & 10.000 & 13.500 \\
CB density of state $\left(\mathrm{cm}^{-3}\right)$ & $2 \times \times 10^{18}$ & $1.5 \times 10^{18}$ & $1.5 \times 10^{18}$ & $1.5 \times 10^{18}$ & $1.8 \times 10^{19}$ \\
VB density of state $\left(\mathrm{cm}^{-3}\right)$ & $1.5 \times 10^{19}$ & $1.8 \times 10^{18}$ & $1.8 \times 10^{18}$ & $1.8 \times 10^{19}$ & $4.0 \times 10^{13}$ \\
$\mu_{\mathrm{n}}$ electron mobility $\left(\mathrm{cm}^{2} / \mathrm{Vs}\right)$ & 100 & 50 & 50 & 50 & 400 \\
$\mu_{\mathrm{h}}$ hole mobility $\left(\mathrm{cm}^{2} / \mathrm{Vs}\right)$ & 12.25 & 20 & 20 & 20 & 210 \\
Donor density ND $\left(\mathrm{cm}^{-3}\right)$ & $1 \times 10^{16}$ & 0 & 0 & 0 & 10 \\
Acceptor density NA $\left(\mathrm{cm}^{-3}\right)$ & 0 & $1 \times 101^{7}$ & $1 \times 10^{17}$ & $5.5 \times 10^{7}$ & $1.0 \times 10^{18}$ \\
Electron thermal velocity $(\mathrm{cm} / \mathrm{s})$ & $3.9 \times 10^{7}$ & $1.0 \times 10^{7}$ & $1 \times 10^{7}$ & $1.0 \times 10^{7}$ & $1.0 \times 10^{7}$ \\
Hole thermal velocity $\left(\mathrm{cm}^{2} / \mathrm{s}\right)$ & $1.4 \times 10^{7}$ & $1.0 \times 10^{7}$ & $1 \times 10^{7}$ & $1.0 \times 10^{7}$ & $1.0 \times 10^{7}$
\end{tabular}

Table 2. Comparison between simulation results with experimental data.

\begin{tabular}{|c|c|c|c|c|c|c|}
\hline & Buffer layer & $\operatorname{Voc}(\mathrm{V})$ & $\mathrm{Jsc}\left(\mathrm{mA} \cdot \mathrm{cm}^{-2}\right)$ & $\mathrm{FF}(\%)$ & $\eta(\%)$ & Reference \\
\hline $\mathrm{CdS}$ & Experimental & & & & & \\
\hline CBD & Deposition methode CBD & 0.74 & 36.6 & 79.3 & 21.7 & {$[10]$} \\
\hline & Simulated & 0.68 & 46.6 & 81.37 & 25.07 & \\
\hline $\mathrm{In}_{2} \mathrm{~S}_{2}$ & Experimental & & & & & \\
\hline ALCVD & Deposition methode CVD & & & & & [11] \\
\hline & Simulated & 0.67 & 44.32 & 79.13 & 16.01 & \\
\hline $\mathrm{ZnS}$ & Experimental & & & & & \\
\hline CBD & Deposition methode CBD & & & & & {$[12]$} \\
\hline & Simulated & 0.62 & 44.93 & 80.41 & 17.1 & \\
\hline $\mathrm{ZnSe}$ & $\begin{array}{c}\text { Experimental } \\
\text { Deposition methode CBD }\end{array}$ & 0.67 & 34.9 & 72.7 & 14.4 & {$[12]$} \\
\hline & Simulated & 0.62 & 46.71 & 78.19 & 18.3 & \\
\hline
\end{tabular}


The conversion efficiency of the simulated CIGS cell is quite close to the experimental result obtained from the real device. The best efficiency is obtained for CdS buffer layer.

\subsection{Effect of Various Thickness of Different Buffer Layers (CdS, ZnSe, ZnSe, $\operatorname{In}_{2} \mathrm{~S}_{2}$ )}

In order to check the effect of various thickness on CIGS photovoltaic parameters $(\mathrm{PV})$, we varied thickness of various buffer layers from $0.1 \mu \mathrm{m}$ to $0.5 \mu \mathrm{m}$ while keeping constant the thickness of the window and absorber layer.

\subsubsection{Effect of Various Thickness of CdS}

Figure 2 shows a simulated various thickness of CdS buffer layer and shows the main photovoltaic parameters Voc, Jsc, FF and $\eta$. In this simulation, the thickness of CdS is varied from $0.1 \mu \mathrm{m}$ to $0.5 \mu \mathrm{m}$. As the thickness of CdS buffer layer is increased, the Jsc has declined from $46.9 \mathrm{~mA} \cdot \mathrm{cm}^{-2}$ to $46.6 \mathrm{~mA} \cdot \mathrm{cm}^{-2}$ therefore a decrease of $7 \%$ and from $0.1 \mu \mathrm{m}$ to $0.5 \mu \mathrm{m}$, Voc decreases of $7 \%$. FF decreases from $81.1 \%$ to $78.8 \%$ therefore a decrease of $3 \%$.

\subsubsection{Effect of Various Thickness of $\mathrm{ZnS}$}

Figure 3 presents a simulated various thickness of $\mathrm{ZnS}$ buffer layer and shows the main photovoltaic parameters Voc, Jsc, FF and $\eta$. In this simulation, the thickness of $\mathrm{ZnS}$ is varied from $0.1 \mu \mathrm{m}$ to $0.5 \mu \mathrm{m}$. The Jsc has declined from $46.04 \mathrm{~mA} \cdot \mathrm{cm}^{-2}$ to $45.75 \mathrm{~mA} \cdot \mathrm{cm}^{-2}$ therefore a decrease of 7\%. F.F drops from $81.57 \%$ to $72.11 \%$ therefore a decrease of $12 \%$. $\eta$ drops from $25.59 \%$ to $25.39 \%$ therefore a decrease of $8 \%$. From $0.1 \mu \mathrm{m}$ to $0.2 \mu \mathrm{m}$ Voc remains constant at 0.68

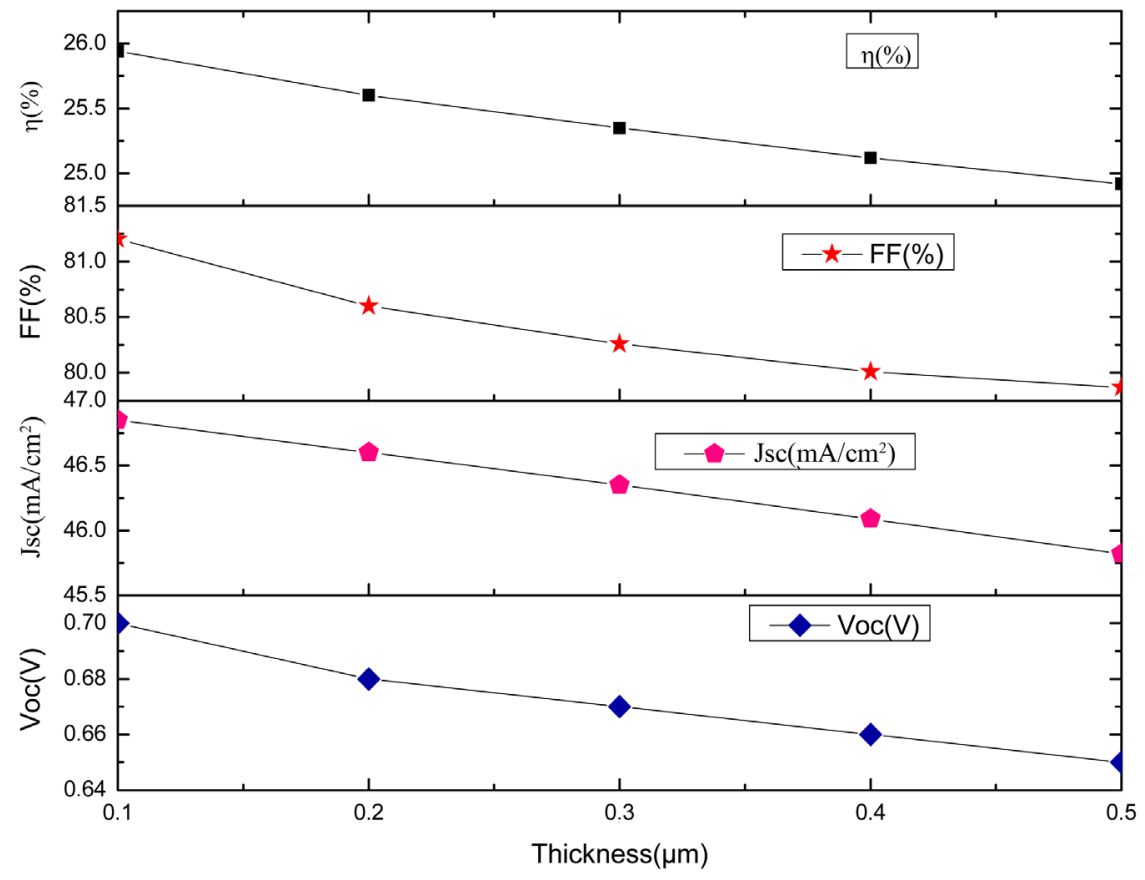

Figure 2. Effect of various thickness of CdS. 
Volt and from $0.2 \mu \mathrm{m}$ to $0.5 \mu \mathrm{m}$ Voc increase from $0.68 \mathrm{~V}$ to $0.76 \mathrm{~V}$ therefore an increase of $12 \%$.

\subsubsection{Effect of Various Thickness of ZnSe}

Figure 4 shows a simulated various thickness of ZnSe buffer layer and shows the main photovoltaic parameters Voc, Jsc, FF and $\eta$. In this simulation, the thickness of ZnSe is varied from $0.1 \mu \mathrm{m}$ to $0.5 \mu \mathrm{m}$. As the thickness of ZnSe buffer layer is increased, the Jsc is declined from $46.83 \mathrm{~mA} \cdot \mathrm{cm}^{-2}$ to $46.07 \mathrm{~mA} \cdot \mathrm{cm}^{-2}$ therefore a decrease of $2 \%$. Voc remain the same.

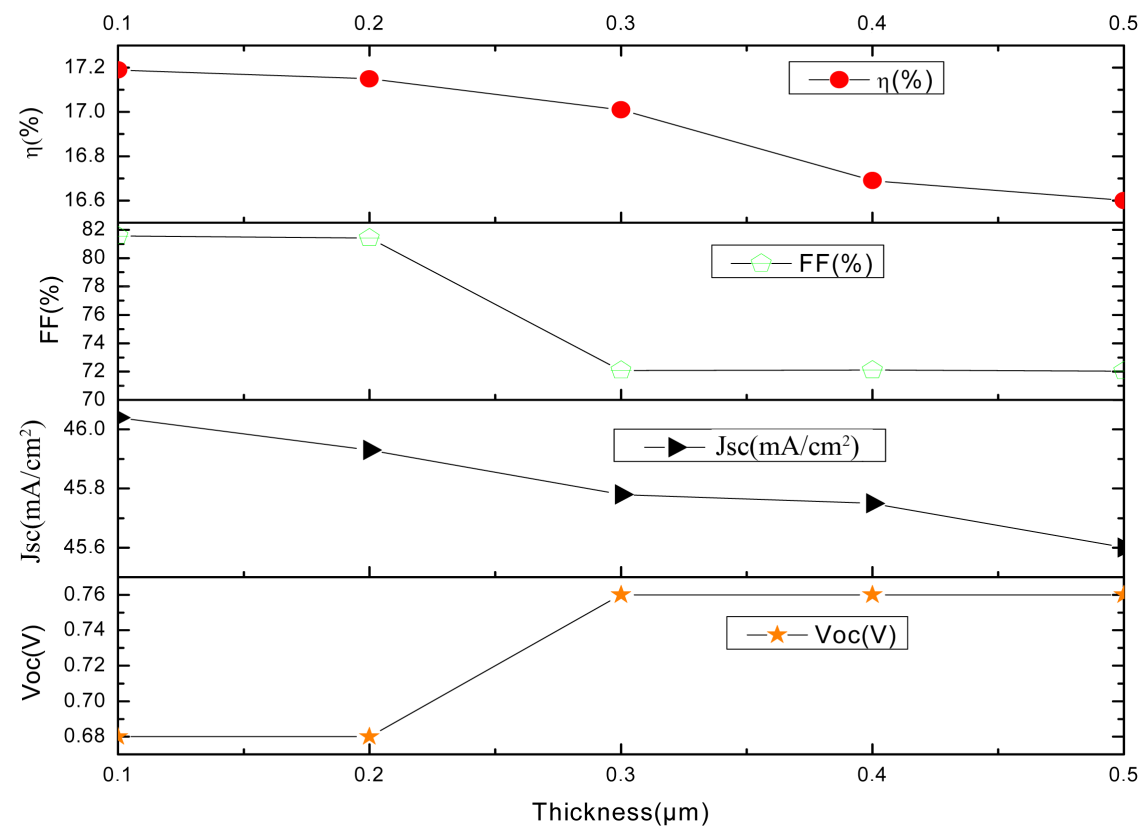

Figure 3. Effect of various thickness of $\mathrm{ZnS}$.

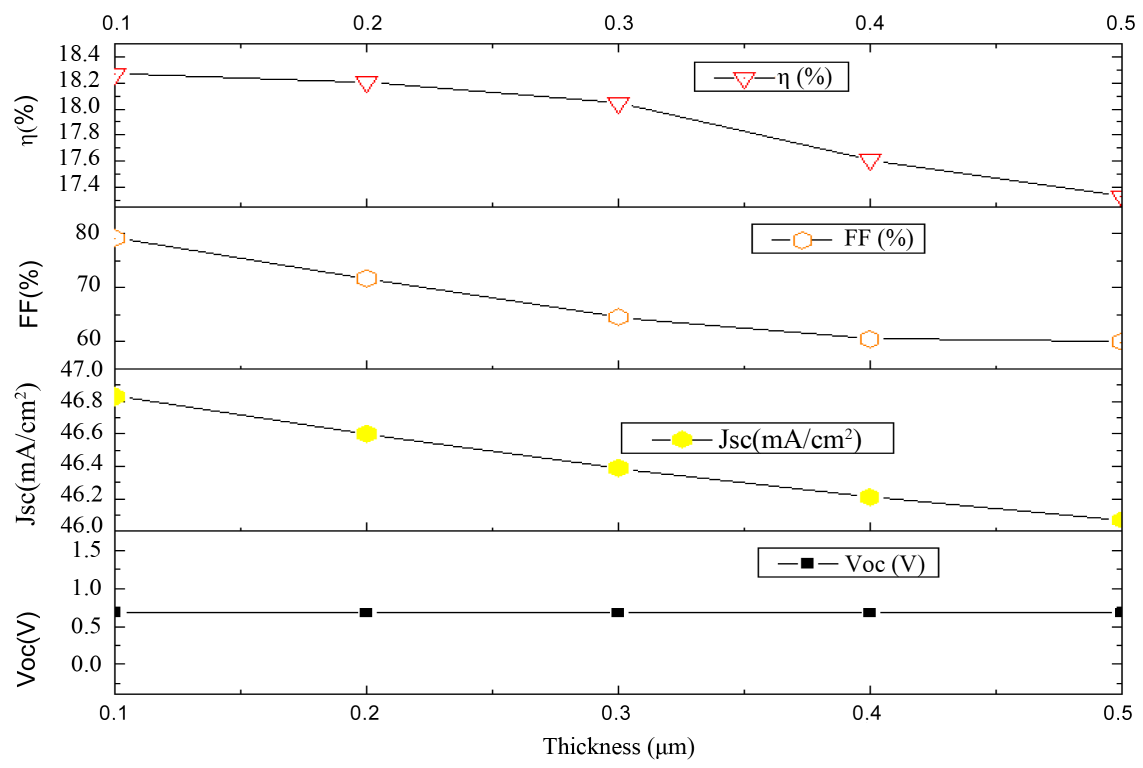

Figure 4. Effect of various thickness of $\mathrm{ZnSe}$. 


\subsubsection{Effect of Various Thickness of $\operatorname{In}_{2} S_{2}$}

Figure 5 shows the performance parameters of the CIGS cell based on different values of thickness of buffer layer $\operatorname{In}_{2} \mathrm{~S}_{2}$. The main parameters without the Voc are degraded by increasing the thickness. Jsc drops from 46.71 to $46.3 \mathrm{~mA} \cdot \mathrm{cm}^{-2}$ therefore a decrease of $9 \%$. F.F drops from $78.19 \%$ to $77.9 \%$ therefore a decrease of $1 \%$. As a result, the conversion efficiency drops from $22.73 \%$ to $22.60 \%$ therefore a decrease of $7 \%$. Voc remains the same.

When the thickness of buffer layer increases, many photons are also absorbed in it layers, reducing thus the number of photons absorbed.

The number of photo generated carriers in the buffer layer therefore decreases and affects negatively the efficiency.

\subsection{Effect of Variable Temperature of CdS and Other Alternatives Layers}

Temperature also affects the band gap because the Varshni Equation [13] shows how band gap is related with temperature.

$$
E_{g}(T)=E_{g}(0)-\frac{\alpha T^{2}}{T+\beta}
$$

$E g_{0}$ is the band gap of the material at $300 \mathrm{~K}$ and $\alpha$ and $\beta$ are empirically determined values specific for each semiconductor. Increase the temperature can be beneficial because these increases can assist in the generation of electron-hole pairs through the transfer of heat energy and increase the rate of diffusion. However, as the temperature increases it begins to affect solar cell performance negatively. This is due to higher temperatures increasing the resistivity of the material's properties [14]. In order to study the effect of the temperature we varied the temperature from $300 \mathrm{~K}$ to $400 \mathrm{~K}$ and we analyzed the main parameters.

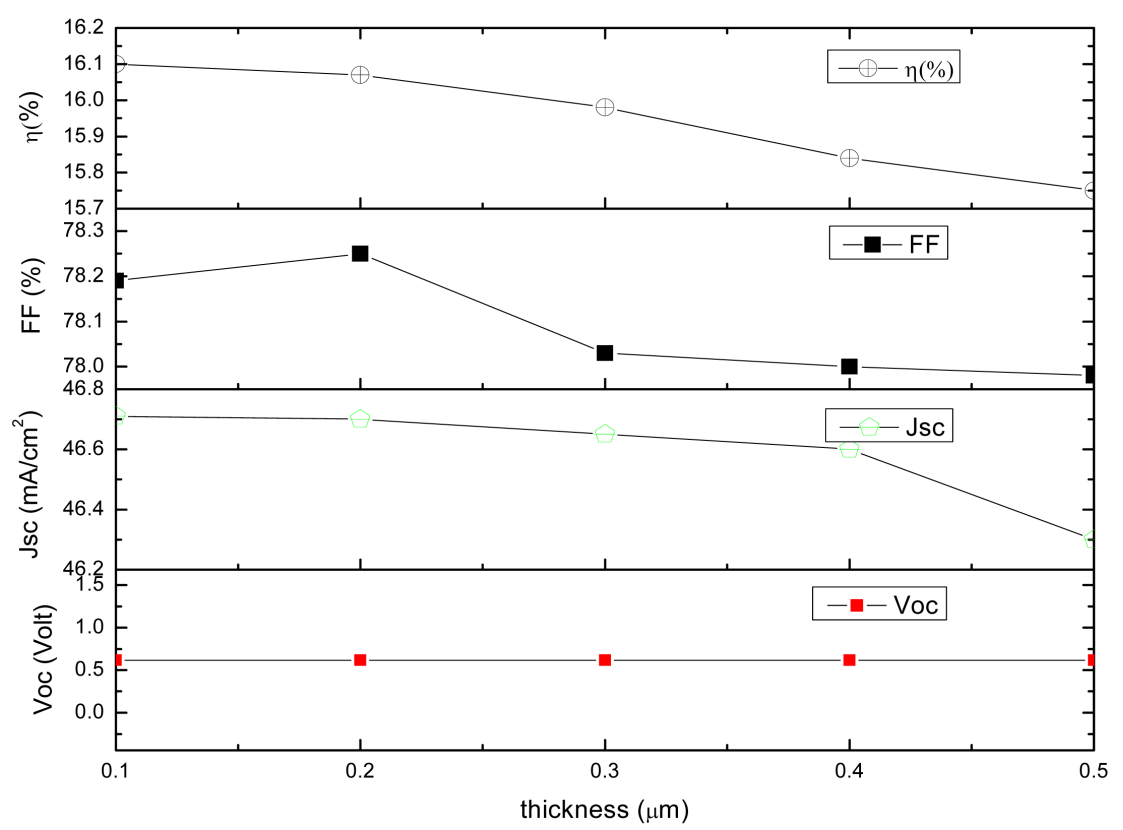

Figure 5. Effect of variousthickness of $\mathrm{In}_{2} \mathrm{~S}_{2}$. 


\subsubsection{Effect of Variable Temperature of CdS}

Figure 6 presents a simulated various temperature of solar cell with CdS buffer layer and shows the main photovoltaic parameters Voc, Jsc, FF and $\eta$. In this simulation, the temperature varies from $300 \mathrm{~K}$ to $400 \mathrm{~K}$. As the temperature is increased, the Jsc is increased from $45.52 \mathrm{~mA} \cdot \mathrm{cm}^{-2}$ to $47.16 \mathrm{~mA} \cdot \mathrm{cm}^{-2}$ therefore an increase of $4 \% \cdot$ Voc drops from 0.68 to 0.08 Volt therefore a decrease of $88 \%$. As a result, the conversion efficiency $\eta$ drops from $24.94 \%$ to $1.02 \%$ therefore a decrease of $96 \%$.

\subsubsection{Effect of Variable Temperature of ZnS}

Figure 7 shows from $300 \mathrm{~K}$ to $400 \mathrm{~K}$ of varied temperature the main photovoltaic parameters Voc, Jsc, FF and $\eta$. In this simulation as the temperature is increased, the Jsc is increased from $45.55 \mathrm{~mA} \cdot \mathrm{cm}^{-2}$ to $47.96 \mathrm{~mA} \cdot \mathrm{cm}^{-2}$ therefore a decrease of $6 \%$. Voc dropped from 0.87 Volt to 0.08 Volt therefore a decrease of $90 \%$ and from $300 \mathrm{~K}$ to $400 \mathrm{~K}$. FF declined from $80.33 \%$ to $30.15 \%$ therefore a decrease of $30 \%$ and the efficiency drops from $17.19 \%$ to $0.64 \%$ therefore a decrease of $96 \%$.

\subsubsection{Effect of Variable Temperature of $\mathrm{ZnSe}$}

Figure 8 shows the performance parameters of the CIGS cell based on different values of temperature. Voc drops from 0.71 to 0.1 Volt therefore a decrease of $86 \%$. Jsc increase from 45.78 to $47.9 \mathrm{~mA} \cdot \mathrm{cm}^{-2}$ therefore an increase of $5 \%$. From 300 to $350 \mathrm{~K}, \mathrm{FF}$ increased 26.96 to 57.97 therefore a increase of $56 \%$ and from $350 \mathrm{~K}$ to $400 \mathrm{~K}$. FF decreased from $57.97 \%$ to $33.13 \%$ therefore a decrease of $20 \%$ and conversion efficiency drops from 18.8 to $4.16 \%$ therefore a decrease of $78 \%$.

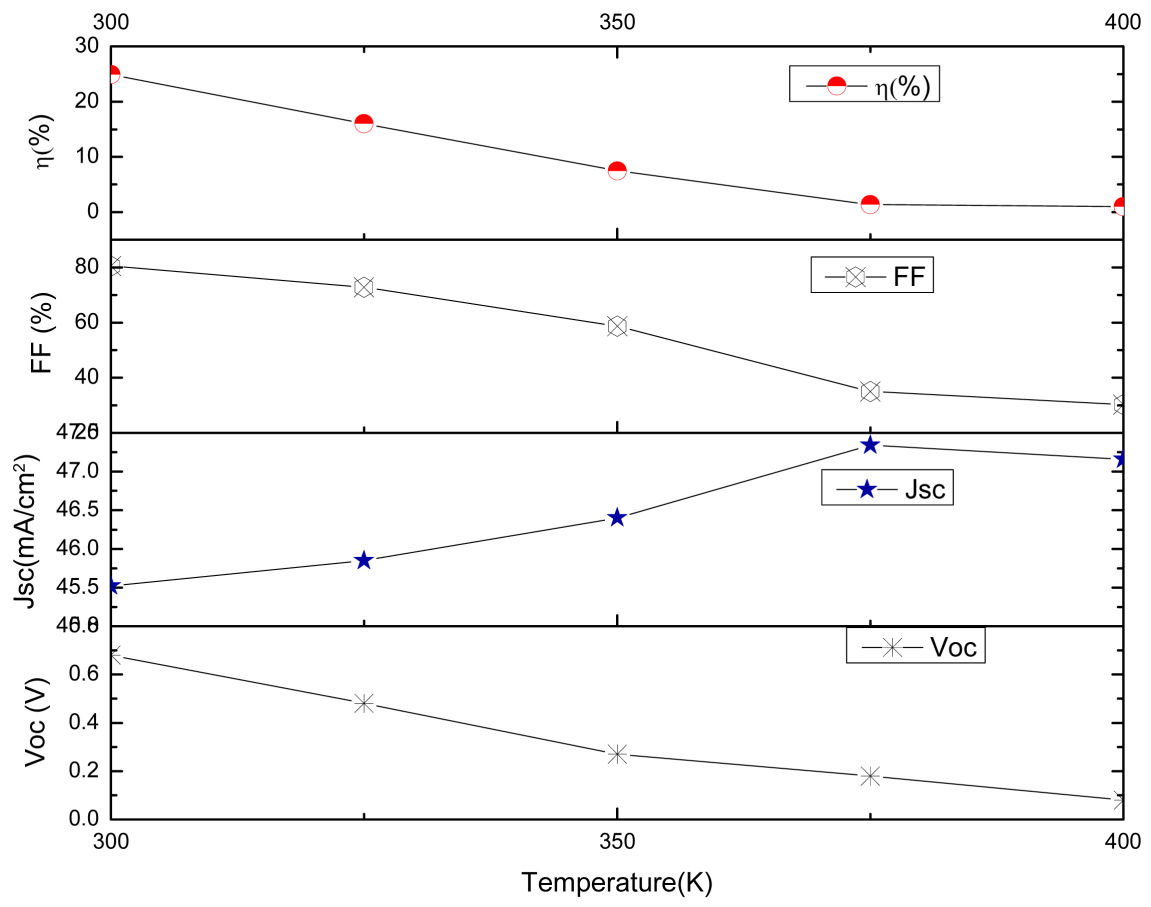

Figure 6. Effect of variable temperature of CdS. 


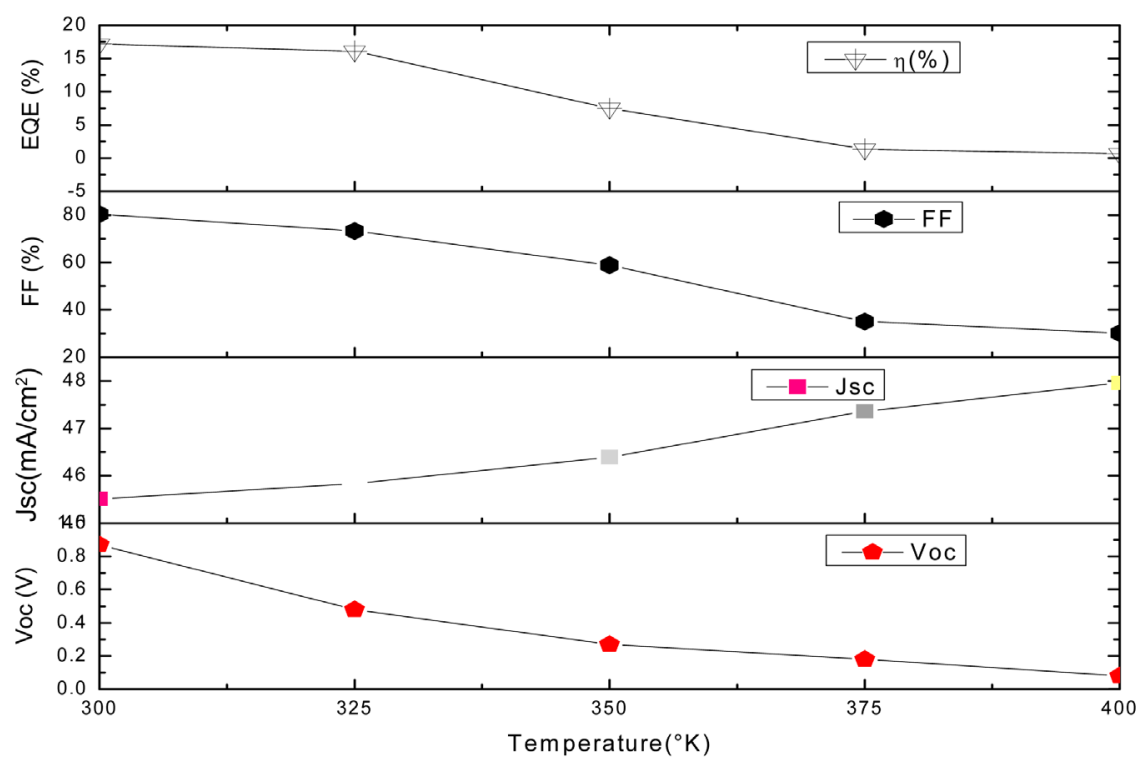

Figure 7. Effect of variable temperature of $\mathrm{ZnS}$.

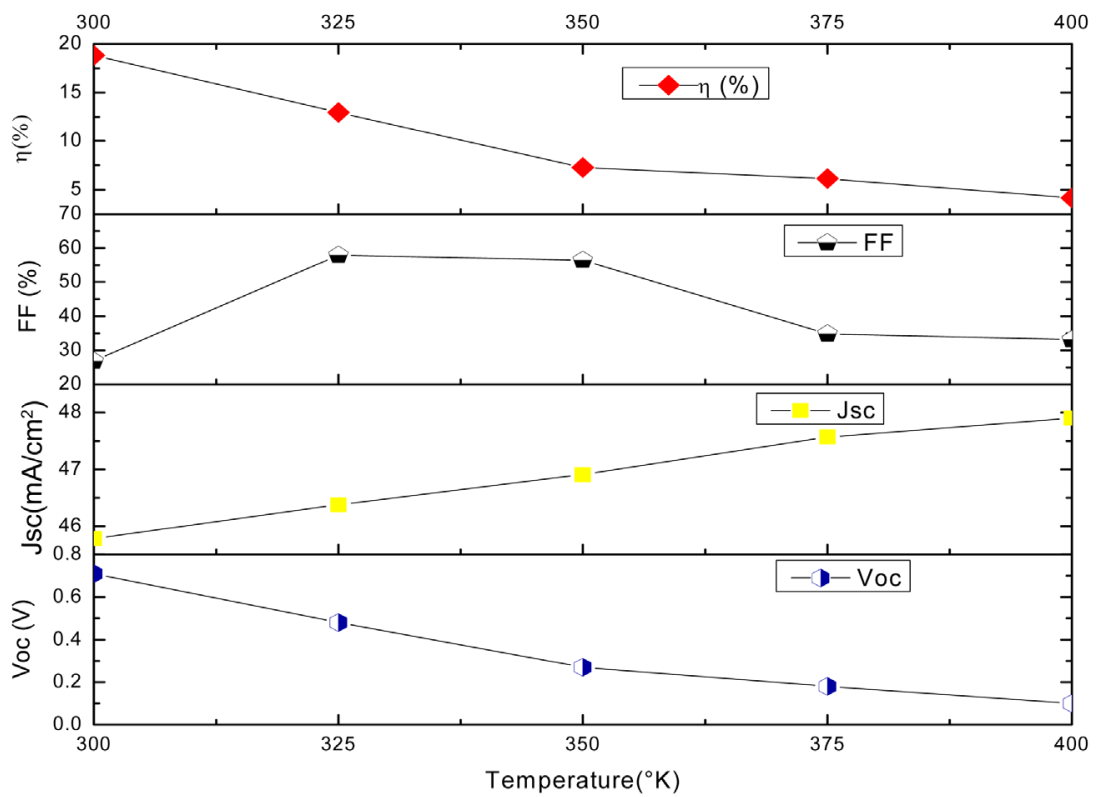

Figure 8. Effect of variable temperature of $\mathrm{ZnSe}$.

\subsubsection{Effect of Variable Temperature of $\operatorname{In}_{2} \mathrm{~S}_{2}$}

Figure 9 shows from $300 \mathrm{~K}$ to $400 \mathrm{~K}$ of varied temperature the main photovoltaic parameters Voc, Jsc, FF and $\eta$. In this simulation as the temperature is increased, the Jsc is increased from $45.58 \mathrm{~mA} \cdot \mathrm{cm}^{-2}$ to $52.19 \mathrm{~mA} \cdot \mathrm{cm}^{-2}$ therefore a decrease of $14 \%$. Voc drops from 0.68 Volt to 0.16 Volt therefore a decrease of $76 \%$ and from 300 to $400 \mathrm{~K}$, FF declined from $79.47 \%$ to $30.65 \%$ therefore a decrease of $30.65 \%$ and the efficiency drops from $16.1 \%$ to $1.24 \%$ therefore a decrease of $92 \%$.

The drop of Voc, Jsc and FF parameters with the varied temperature results in a drastic reduction of the efficiency conversion and we explain this by the fact 


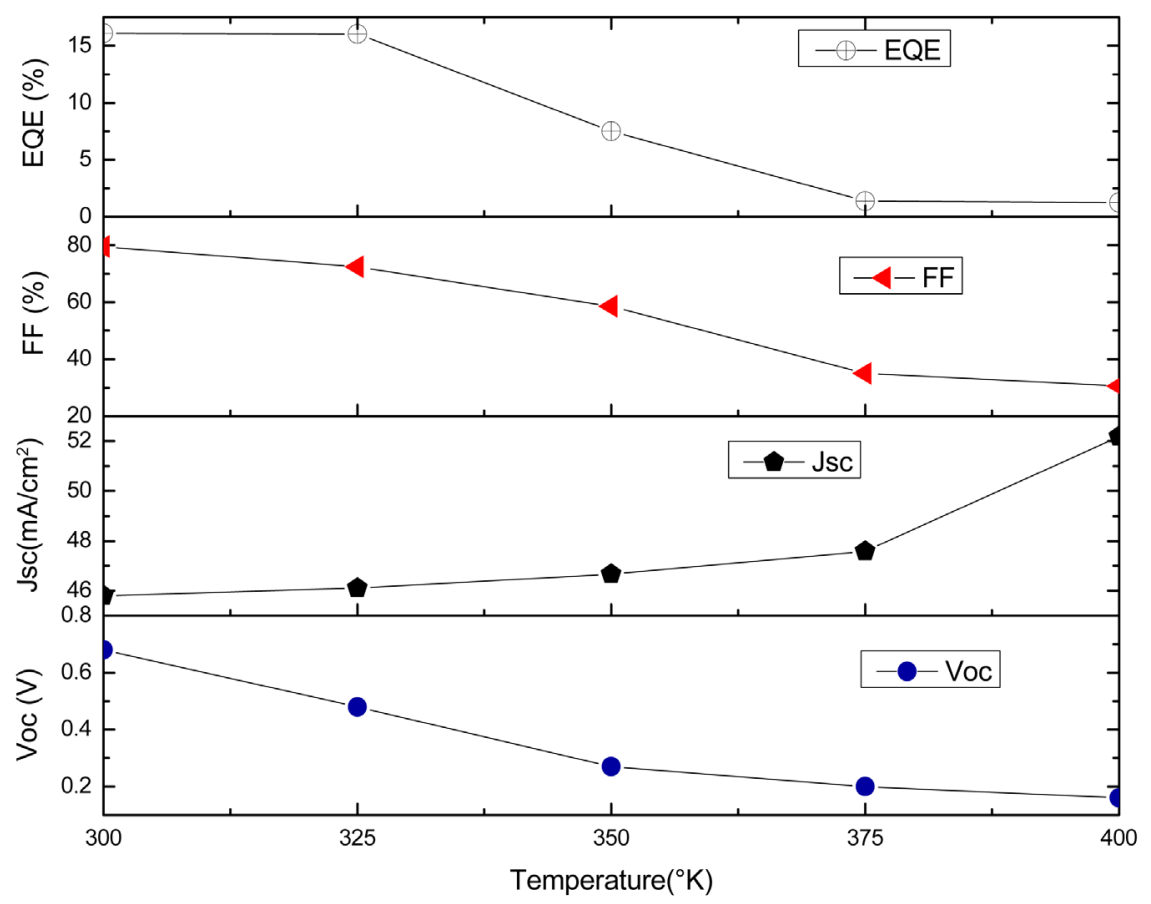

Figure 9. Effect of variable temperature of $\operatorname{In}_{2} \mathrm{~S}_{2}$.

that when the temperature increases these electrons become unstable and recombine with the holes before the carriers could reach the depletion region and collected [15]. The efficiency of the cells of PV parameter at higher temperature can be explained by other parameter like hole and the electron mobility carrier concentrations and band gaps of material would be affected high temperature [16].

\subsection{Effect of Dual Buffer Layer}

In order to improve the efficiency we simulated double buffer layer $\mathrm{ZnS} / \mathrm{CdS}$.

Figure10 shows energy band of $\mathrm{ZnS} / \mathrm{CdS}$.

Table 3 shows that the main photovoltaic parameters are better with $\mathrm{ZnS} / \mathrm{CdS}$ double layer than the CIGS solar cell with only ZnS layer and the same as that of the CIGS solar cell with conventional CdS layer and shows that efficiency increases from $25.07 \%$ to $25.87 \%$ so an increase of $3 \%$.

We obtained a better efficiency that with an only $\mathrm{ZnS}$ layer because of insertion of CdS layer who have a superior junction quality [16].

Figure 11 shows the spectral response for CIGS cell with the dual buffer layer $\mathrm{ZnS} / \mathrm{CdS}$ and show that $\mathrm{ZnS} / \mathrm{CdS}$ double layer has improved efficiency in the wavelength ranges of $400-600 \mathrm{~nm}$ and has been proved by experiences [18]. The better performance with the $\mathrm{ZnS} / \mathrm{CdS}$ double buffer layer may be attributed to less defect density at the CdS/CIGS and $\mathrm{ZnO} / \mathrm{ZnS}$ interface. Another possibility of the better performance for the double buffer layer structure may be due to favourable band alignment at the ZnS/CdS/CIGS interface, structure in case of a wider gap CIGS due to low electron affinity of the $\mathrm{ZnS}$ material. 


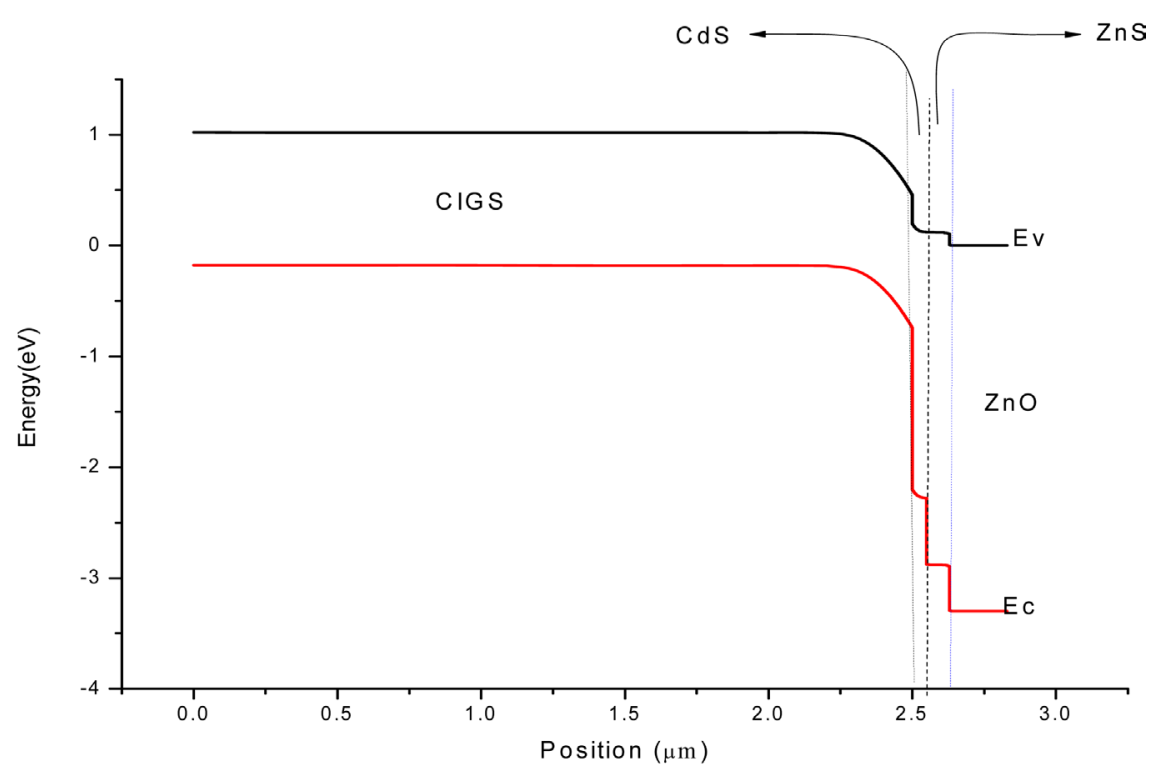

Figure 10. Energy band of $\mathrm{ZnS} / \mathrm{CdS}$.

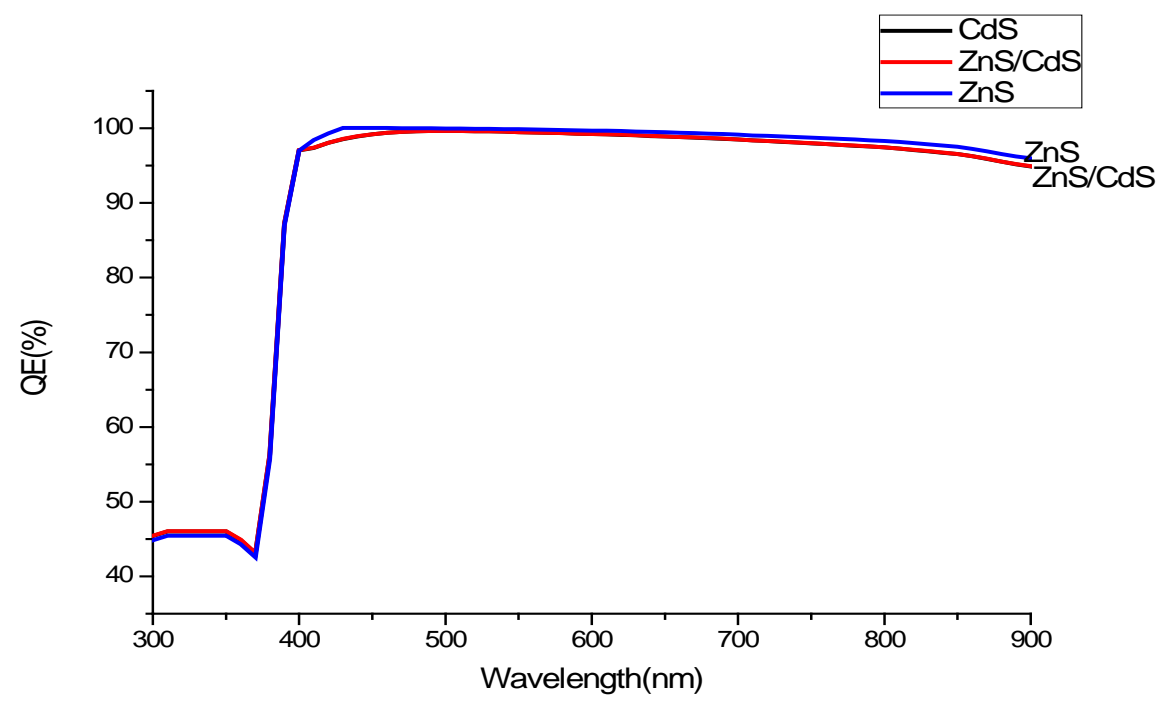

Figure 11. Spectral response for CIGS cell with a dual buffer layer ZnS/CdS.

\section{Conclusion}

The CdS buffer layer is replaced with fours materials. We first simulated a single buffer layer (CdS, ZnS, ...) and determined the optimized CIGS solar cell and secondly we simulated a double buffer layer $\mathrm{ZnS} / \mathrm{CdS}$ and the simulation proves that we have a good efficiency than a single buffer layer CdS or ZnS. The impact of changing material in the buffer layer of cell structure is evaluated and the optimized efficiency is also determined using simulation tools. Simulation result shows that these materials can be used as buffer layer instead of toxic CdS in CIGS solar cell. Numerical simulation performed in this paper could contribute to fabricating a CIGS free solar cell. The results of simulations with the Solar Cells Capacitance SCAPS reveal that CIGS solar cells with alternative buffer layers can be 
Table 3. PV parameters of simulated and experimental double buffer layer ZnSe/CdS.

\begin{tabular}{cccccc}
\hline Buffer layer & Voc & Jsc $\left(\mathrm{mA} \cdot \mathrm{cm}^{-2}\right)$ & FF (\%) & $\eta(\%)$ & Reference \\
\hline CdS (experimental) & 0.69 & 30.9 & 0.72 & 15.3 & {$[17]$} \\
CdS (simulated) & 0.68 & 46.60 & 81.37 & 25.07 & \\
ZnS (experimental) & 0.37 & 28.6 & 0.5 & 5.34 & {$[17]$} \\
ZnS (simulated) & 0.67 & 44.32 & 79.13 & 16.01 & \\
ZnS/CdS (experimental) & 0.69 & 30.8 & 0.76 & 16.4 & {$[17]$} \\
ZnS/CdS (simulated) & 0.67 & 47.42 & 82.33 & 25.87 & \\
\hline
\end{tabular}

achieved. We concluded that $\mathrm{ZnSe}$ and $\mathrm{ZnS}$ can be used as alternative material to CdS, as it has serious environmental problems.

\section{Acknowledgements}

The authors are grateful to Prof Marc Burgelman and his colleagues at the University of Gent for providing the SCAPS-1D software reported in this document.

\section{References}

[1] Résolution sur la conférence de Paris sur le climat (COP 21). [Paris Climate Change Agreement (COP 21).] http://www.jugendparlament.lu/files/2015/07/Résolution_COP21.pdf

[2] http://www.PV-magazine.com

[3] Jamil, S. N-Abdulla, N. and Mohamned, K. (2012) Design and Fabrication Heterojunction Solar Cell of Si-ZnO Thin Film. Proceeding of the International Conference Nanomaterial Applications and Proprieties, 1, N4.

[4] Yamada, A., Chaisitsak, S., Ohtake, Y., and Konagai, M. (1998) High Efficiency Cu (In, Ga) $\mathrm{Se}_{2}$ Thin-Film Solar Cells with Novel Znnxsey Buffer Layer. Proceeding of the 2nd World Conference of Photovoltaic Energy Conversion, 1, 1177-1180.

[5] Enaoui, A., Eisele, W., Lex-Steiner, M.C., Riedl, W. And Karg, F. (2000) Cd-Free Cu (Ga, In) (SSe) ${ }_{2}$ Thin Film Solar Cells and Mini-Modules. 16th European Photovoltaic Solar Energy Conference, Glasgow, 1-5 May 2000, 682-685.

[6] Pudov, A.O. (2005) Impact of Secondary Barriers on CuIn ${ }_{1-x} \mathrm{Ga}_{x} \mathrm{Se}_{2}$ Solar-Celloperation PhD Dissertation, Colorado State University Fort Collins, Colorado.

[7] Kessler, J., Ruckl, M., Harriskos, D. and Ruthle Schow, U. (2013) Interface Engineering between $\mathrm{CuInSe} 2$ and $\mathrm{ZnO}$. Processing of the 23 rd IEEE Photovoltaic Specialist Conference, Louisville, 16-21 June 2013, 447-452.

[8] Burgelman, M., Nollet, P. and Degrave, S. (2000) Modelling Polycrystalline Semiconductor Solar Cells. Thin Solid Films, 361-362, 527-53.

https://doi.org/10.1016/S0040-6090(99)00825-1

[9] Malmstrom, J., Wennerberg, J., Khoshsirat, N., Amziah, N., Yunus, M., Hamidon, N.M. and Shafie, S. (2015) Analysis of Absorber Layer Properties Effect on CIGS Solar Cell Performance Using SCAPS. Optik, 125, 681-686.

[10] Jackson, P., Harriskos, D., Wuerz, R., Kiowski, O., Bauer, A., Friedlmeier, T.M. and Powalla, M. (2014) Properties of $\mathrm{Cu}(\mathrm{In}, \mathrm{Ga}) \mathrm{Se}_{2}$ Solar Cells with New Record Efficiencies up to $21.7 \%$. Physica Status Solidi, 9, 62-67. 
[11] Spiering, S., Eicke, A., Hariskos, D., Powalla, M., Naghavi, N. and Lincot, D. (2004) Large-Area Cd-Free CIGS Solar Modules with $\operatorname{In}_{2} \mathrm{~S}_{3}$ Buffer Layer Deposited by ALCVD. Thin Solid Films, 451-452, 562-566. https://doi.org/10.1016/j.tsf.2003.10.090

[12] Varshni, Y. (1967) Temperature Dependence of the Energy Gap in Semi-Conductor. Physica, 34, 149-154. https://doi.org/10.1016/0031-8914(67)90062-6

[13] Ennaoui, A., Eisele, W., Lux-Steiner, M., Niesen, T.P. and Karg, F. (2003) Highly Efficient $\mathrm{Cu}(\mathrm{Ga}, \mathrm{In})(\mathrm{S}, \mathrm{Se})_{2}$ Thin Film Solar Cells with Zinc Compound Buffer Layers. Thin Solid Films, 431-432, 335-339. https://doi.org/10.1016/S0040-6090(03)00155-X

[14] Brian, S. (2010) The Effect of Temperature on the Optimization of Photovoltaic Cells Using Silvaco ATLAS. Dissertation for Master. Electrical Engineering Naval Postgraduate School, Monterey.

[15] Chelvanathan, P., Hossain, M.I. and Amin, N. (2010) Performance Analysis of Copper-Indium-Gallium-Diselenide (CIGS) Solar Cells with Various Buffer Layers by SCAPS. Current Applied Physics, 10, S387-S391.

https://doi.org/10.1016/j.cap.2010.02.018

[16] Nakada, T. and Mizutani, M. (2002) 18\% Efficiency Cd-Free Cu(In,Ga)Se ${ }_{2}$ Thin-Film Solar Cells Fabricated Using Chemical Bath Deposition (CBD)-ZnS Buffer Layers. Japan Society of Applied Physics, 41, 165. https://doi.org/10.1143/JJAP.41.L165

[17] Islam, M.M, Ishizuka, S., Yamada, A., Sakurai, K., Niki, S., Sakurai, T. and Akimoto, K. (2009) CIGS Solar Cell with MBE-Grown ZnS Buffer Layer. Solar Energy Materials \& Solar Cells, 93, 970-972. https://doi.org/10.1016/j.solmat.2008.11.047

[18] Hyeop Shin, D., Larina, L., Hoon Yoon, K. and Ahn, B.T. (2010) Fabrication of $\mathrm{Cu}(\mathrm{In}, \mathrm{Ga}) \mathrm{Se}_{2}$ Solar Cell with ZnS/CdS Double Layer as an Alternative Buffer. Current Applied Physics, 10, S142-S145. https://doi.org/10.1016/j.cap.2009.11.019 